\title{
Blood Purification
}

Walter H. Hörl, M.D., Ph.D., F.R.C.P.

Chairman - 1998 Medical

Advisory Board

\section{Introductory Comments}

The Extramural Grant Program (EGP) is an international research funding source established in 1989 under the direction and influence of Lee W. Henderson, M.D., F.A.C.P., Executive Director. The objectives of the EGP are to stimulate and support new research ideas through the funding of science in the field of renal disease, and to ultimately improve the quality of life for patients with end-stage renal disease.

Over the past ten years, the Extramural Grant Program's Medical Advisory Board has awarded more than \$24 million dollars to 221 investigators representing 20 countries. Funded research encompasses both basic science (51\%) and applied clinical studies (49\%). A breakdown of the research can be found in Figure 1.

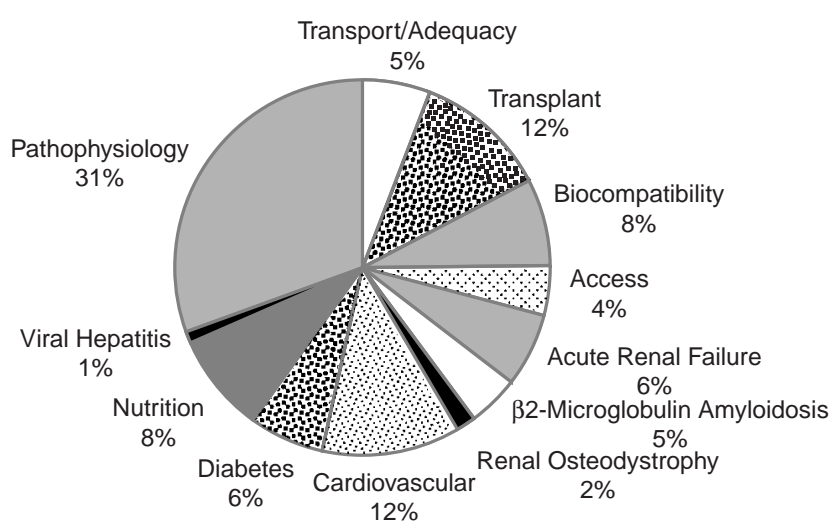

Fig. 1. EGP Research Focus.

Grants funded through the EGP are one to three years in length and average US $\$ 40,000$ per year. Research highlights are presented each year at the Annual Extramural Grant Program Scientific Meeting and are published in a special issue of this journal.

In 1998, the Annual EGP Scientific Meeting was held on May 28-29 in Chicago, Illinois. Sixty-five recipients presented the
Table 1: 1998 Medical Advisory Board

\begin{tabular}{|ll|}
\hline J. Stewart Cameron, BSc, MD, FRCP & United Kingdom \\
Tzen Wen Chen, MD & Taiwan \\
Tilman B. Drüeke, MD & France \\
David C.H. Harris, MD, BS, FRACP & Australia \\
J. Harold Helderman, MD, FACP & United States \\
Walter H. Hörl, MD, PhD, FRCP & Austria \\
Julie R. Ingelfinger, MD & United States \\
Yoshindo Kawaguchi, MD & Japan \\
Saulo Klahr, MD & United States \\
Giuseppe Remuzzi, MD & Italy \\
\hline
\end{tabular}

results of their research to members of the Medical Advisory Board (Table 1), the other EGP investigators, the Baxter scientific community and invited guests. The 21 grant recipients who had completed a minimum of three years of research gave slide presentations followed by a discussion period. The other 44 research projects were presented in poster format. This special issue contains abstracts from all presentations, transcripts of the discussions and publications resulting from each grant. It will be apparent from reading these proceedings that the EGP is funding some of the most exciting research being performed in the area of renal failure and its treatment.

The Extramural Grant Program is committed to scientific investigation into the cause and treatment of kidney disease, and will continue to support researchers and scientists throughout the world until at least 2001.

For additional information about the Extramural Grant Program, please visit our website at www.baxter.com/egp or contact us at the following address:

Baxter Healthcare Corporation

Renal Division

The Extramural Grant Program

1620 Waukegan Road

McGaw Park, Illinois USA 60085-6730

Tel. +1 (847) 473 6137; Fax +1 (847) 4736902

\section{KARGER}

Fax +4161306 1234 E-Mail karger@karger.ch www.karger.com
(C) 1999 S. Karger AG, Base

0253-5068/99/0177-001\$17.50/0

Accessible online at:

http://BioMedNet.com/karger 